\title{
Improved Electrochemical Performance of NaVOPO 4 Positive Electrodes at Elevated Temperature in an Ionic Liquid Electrolyte
}

\section{AUTHOR(S):}

Chen, Chih-Yao; Matsumoto, Kazuhiko; Nohira, Toshiyuki; Hagiwara, Rika

\section{CITATION:}

Chen, Chih-Yao ... [et al]. Improved Electrochemical Performance of NaVOPO 4 Positive Electrodes at Elevated Temperature in an Ionic Liquid Electrolyte. Journal of The Electrochemical Society 2015, 162(10): A2093-A2098

\section{ISSUE DATE:}

2015-08-04

URL:

http://hdl.handle.net/2433/202596

\section{RIGHT:}

(C) The Electrochemical Society, Inc. 2015. All rights reserved. Except as provided under U.S. copyright law, this work may not be reproduced, resold, distributed, or modified without the express permission of The Electrochemical Society (ECS). The archival version of this work was published in [doi: 10.1149/2.0691510jes J. Electrochem. Soc. 2015 volume 162, issue 10, A2093-A2098],; この論文は出版社版でありません。引用の際には出版社版をご磼認ご利用ください。； This is not the published version. Please cite only the published version. 
Improved Electrochemical Performance of $\mathrm{NaVOPO}_{4}$

\section{Liquid Electrolyte}

4

5

6 Chih-Yao Chen ${ }^{\text {a }}$, Kazuhiko Matsumoto ${ }^{\text {a, }}$, Toshiyuki Nohira ${ }^{\text {b, * }}$, and Rika Hagiwara ${ }^{\text {a }}$ *

${ }^{a}$ Graduate School of Energy Science, Kyoto University, Sakyo-ku, Kyoto 606-8501, Japan

8 ${ }^{b}$ Institute of Advanced Energy, Kyoto University, Gokasho, Uji, Kyoto 611-0011, Japan

9

E-mail addresses: k-matsumoto@energy.kyoto-u.ac.jp;

Tel: $+81-75-753-5822$

Fax: $+81-75-753-5906$ 


\section{Abstract}

Sodium secondary batteries operating in a wide temperature range are attractive as large-scale energy storage devices, and ionic liquid electrolytes are suitable for this purpose. In this study, $\mathrm{NaVOPO}_{4}$ has been investigated as positive electrode material for $\mathrm{Na}$ secondary batteries, and its electrochemical performance has been examined in the $\mathrm{Na}$ [FSA $]-\left[\mathrm{C}_{3} \mathrm{C}_{1}\right.$ pyrr] $]$ FSA $]$ ionic liquid $\left(\mathrm{C}_{3} \mathrm{C}_{1}\right.$ pyrr $=$ $N$-methyl- $N$-propylpyrrolidinium and FSA $=$ bis(fluorosulfonyl)amide) at 298 and $363 \mathrm{~K}$. The $\mathrm{NaVOPO}_{4}$ electrode exhibits a reversible capacity of 60 and $101 \mathrm{mAh}$ $\mathrm{g}^{-1}$ at 298 and $363 \mathrm{~K}$, respectively. Acceptably good rate capability is achieved at $363 \mathrm{~K}$, as $76 \%$ of the maximum capacity is maintained at $5 \mathrm{C}$ rate. Cyclability tests prove good reversibility of the material, in which $74 \%$ of the initial specific capacity maintains over 300 cycles at $363 \mathrm{~K}$. XRD measurements reveal that the charge-discharge process of $\mathrm{NaVOPO}_{4}$ involves a single-phase reaction. Galvanostatic intermittent titration technique (GITT) analysis highlights a 3-5-fold increase of the apparent $\mathrm{Na}$ chemical diffusion coefficient in $\mathrm{NaVOPO}_{4}$ upon increasing the temperature from 298 to $363 \mathrm{~K}$, which is reflected in the superior electrochemical performance at $363 \mathrm{~K}$ than at $298 \mathrm{~K}$. 


\section{Introduction}

Sodium secondary batteries have attracted considerable attention as alternatives or complements to the prevailing Li-ion batteries, owing to their virtually unlimited

41 supply, low material cost, and large worldwide availability. ${ }^{1-3}$ Research on $\mathrm{Na}$

42 secondary batteries has continued to gain momentum from the systematic

43 extrapolation of the well-established knowledge regarding lithium ion batteries. The

44 larger ionic radii of $\mathrm{Na}^{+}(1.02 \AA)$ than $\mathrm{Li}^{+}(0.76 \AA)^{3}$ was formerly deemed to frustrate

45 the reversible insertion and fast transport of sodium within rigid inorganic hosts. ${ }^{4}$

46 However, a recent computational study suggested that the diffusion of $\mathrm{Na}$ can be

47 faster than that of $\mathrm{Li}$ in certain crystal structures. ${ }^{5}$ The milder Lewis acidity of $\mathrm{Na}^{+}$

48 than $\mathrm{Li}^{+}$has also been shown to lead to a commonly smaller desolvation energy in

49 polar solvents. ${ }^{6-8}$ Since the desolvation process of alkali ions highly influences their

50 kinetics of insertion at the electrolyte interface, ${ }^{9}$ the relatively low desolvation energy

51 coupled with the facile bulk diffusion may open up new appealing possibilities for

52 high-power Na secondary batteries. ${ }^{3}$

53 One of the main issues for Na secondary battery systems is their inferior energy

54 densities compared to the Li-based ones, ${ }^{3,5,10}$ which is caused by (1) the larger mass

55 (22.99 $\mathrm{g} \mathrm{mol}^{-1}$ for $\mathrm{Na}$ and $6.94 \mathrm{~g} \mathrm{~mol}^{-1}$ for Li) and (2) the higher redox potential 
57 counteract these intrinsic limitations, positive electrode materials that enable the

58 realization of high capacity and high operating voltages are essential for $\mathrm{Na}$ secondary

59 batteries. In this respect, vanadium-based phosphates are gaining increasing

60 prominence. ${ }^{10-18}$ Relatively high operating potentials (vs. $\mathrm{Na}^{+} / \mathrm{Na}$ ) were achieved for

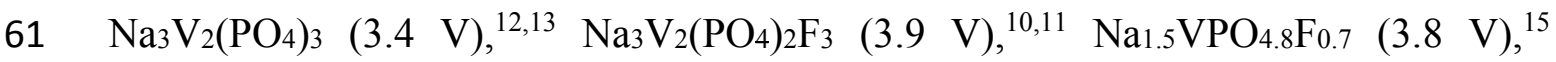

$62 \mathrm{Na}_{7} \mathrm{~V}_{4}\left(\mathrm{P}_{2} \mathrm{O}_{7}\right)_{4} \mathrm{PO}_{4}(3.88 \mathrm{~V}),{ }^{16,17}$ and $\mathrm{Na}_{2} \mathrm{VOP}_{2} \mathrm{O}_{7}(3.8 \mathrm{~V}) .{ }^{18}$ The strong inductive effect

63 of the $\mathrm{PO}_{4}{ }^{3-}$ polyanion alters the covalent character of $\mathrm{V}-\mathrm{O}$ (or $-\mathrm{F}$ ) bonds and

64 moderates the energetics of the vanadium redox couple, resulting in favorable

65 operating potentials for these compounds. ${ }^{19-21}$ However, most of the above electrode

66 materials face limitations in terms of theoretical capacity (ca. 90-120 $\mathrm{mAh} \mathrm{g}^{-1}$ ),

67 because of the heavy polyanion group. ${ }^{12,13,16-18}$

68

The vanadium-based phosphate, $\mathrm{NaVOPO}_{4}$, characterized by a moderately high

69 operating potential $\left(3.6 \mathrm{~V}\right.$ vs. $\left.\mathrm{Na}^{+} / \mathrm{Na}\right)$ as well as a relatively large theoretical capacity

$70\left(145 \mathrm{mAh} \mathrm{g}^{-1}\right),{ }^{22}$ provides one of the highest theoretical energy densities (ca. $530 \mathrm{Wh}$

$71 \mathrm{~kg}^{-1}$ ) among the positive electrode materials for Na secondary batteries. ${ }^{10,11,15}$ Despite

72 such an attractive energy density, however, $\mathrm{NaVOPO}_{4}$ has not been significantly

73 explored as positive electrode material as yet. Earlier studies on $\mathrm{NaVOPO}_{4}$ mostly

74 focused on its synthesis and structural properties. ${ }^{23-25}$ The only electrochemical report

75 to date, by Song et al., revealed that $62 \%\left(90 \mathrm{mAh} \mathrm{g}^{-1}\right)$ of the theoretical capacity can 
76 be realized at room temperature in $1 \mathrm{M} \mathrm{NaClO}_{4} /$ propylene carbonate (PC); however,

77 other important electrode characteristics such as rate capability and long-term

78 cyclability, as well as reaction mechanism, remain to be investigated. ${ }^{22}$

80 for a battery, which is dominated by the performance of positive electrode materials in

81 many Li and Na secondary batteries. On the other hand, the electrolyte also represents

82 a key component that governs many important properties of batteries. ${ }^{26-28}$ The

83 electrolytes investigated for $\mathrm{Na}$ secondary batteries are mainly based on organic

84 solvents, following similar approaches to those developed for lithium ion batteries. ${ }^{3,28}$

85 As the interest in Na secondary batteries distributed over a much more diversified and

86 global manner, the electrolytes of choice is not a single one. ${ }^{28}$ Ionic liquids (ILs),

87 characterized by a suite of unique properties such as nonflammability, nonvolatility,

88 as well as good thermal and electrochemical stability, show considerable potential as

89 advanced electrolytes. ${ }^{29-35}$ Improved electrochemical performance has been

90 demonstrated for cells adopting IL electrolytes, compared to those involving organic

91 electrolytes. ${ }^{33-35}$

92 In our previous studies, the feasibility of a series of bis(fluorosulfonyl)amide

93 (FSA)-based IL electrolytes for Na batteries has been verified. ${ }^{36-38}$ The wide liquidus

94 range of the $\mathrm{Na}[\mathrm{FSA}]-\left[\mathrm{C}_{3} \mathrm{C}_{1}\right.$ pyrr $][\mathrm{FSA}]$ IL $\quad\left(\mathrm{C}_{3} \mathrm{C}_{1}\right.$ pyrr $=$ 
$95 \mathrm{~N}$-methyl- $N$-propylpyrrolidinium) allowed us to investigate the charge-discharge

96 behavior of targeted electrode materials from low $(253 \mathrm{~K})$ to elevated temperatures

$97(363 \mathrm{~K}) \cdot{ }^{39-41}$ The results revealed a considerable enhancement in reversible capacity

98 and rate capability with increasing temperature for $\mathrm{Na}_{2} \mathrm{MnSiO}_{4},{ }^{39} \mathrm{Na}_{2} \mathrm{FeP}_{2} \mathrm{O}_{7},{ }^{40}$ and

$99 \mathrm{Na}_{1.56} \mathrm{Fe}_{1.22} \mathrm{P}_{2} \mathrm{O}_{7}{ }^{41}$ The performance of batteries with conventional organic electrolyte

100 solvents have been rarely investigated at temperatures greater than $328 \mathrm{~K}$, above

101 which poor storage and inferior cycling behaviors are generally observed. ${ }^{42,43}$ Since a

102 concrete improvement in electrochemical properties was observed in IL electrolytes at

103 elevated temperatures, operation at above room temperature is preferable and also

104 practicable for electric vehicle and stationary storage applications. ${ }^{34}$ In the present

105 work, the electrochemical properties of $\mathrm{NaVOPO}_{4}$ are investigated in

$106 \mathrm{Na}$ [FSA]-[C ${ }_{3} \mathrm{C}_{1}$ pyrr][FSA] IL electrolyte at 298 and $363 \mathrm{~K}$. With the aim to

107 understand the characteristics of $\mathrm{NaVOPO}_{4}$ in higher detail, here we investigate the

108 rate capability, the cyclability, as well as the structural variation of the materials upon

109 electrochemical cycling. Furthermore, the galvanostatic intermittent titration

110 technique (GITT) has been used to elucidate the Na intercalation kinetics within the

111 material.

\section{Experimental}


114 from $\mathrm{Na}\left(\mathrm{CH}_{3} \mathrm{COO}\right), \mathrm{NH}_{4} \mathrm{VO}_{3},\left(\mathrm{NH}_{4}\right)_{2} \mathrm{HPO}_{4}$ and citric acid, according to a reported

115 procedure. ${ }^{22}$ Equal amounts of the starting materials were dissolved in ultrapure water

116 with magnetic stirring at $343 \mathrm{~K}$. After a clear blue solution formed, the mixture was

117 further dried at $353 \mathrm{~K}$ to transform the solution from sol to gel. The gel was initially

118 heated at $573 \mathrm{~K}$ for $4 \mathrm{~h}$ and then at $773 \mathrm{~K}$ for $4 \mathrm{~h}$ in air. The as-prepared $\mathrm{NaVOPO}_{4}$

119 (denoted as NVP-AP) was thoroughly mixed with acetylene black (AB, 5:1 in weight)

120 via a high-energy planetary ball-milling (Fritsch Pulverisette 7 Premium Line) for $2 \mathrm{~h}$

121 and $8 \mathrm{~h}$ at $700 \mathrm{rpm}$ (the corresponding material samples are hereafter denoted as

$122 \mathrm{NVP} / \mathrm{AB}-2 \mathrm{~h}$ and NVP/AB-8h, respectively).

123 The crystal structure of NVP-AP was determined by an X-ray diffractometer

124 (Rigaku SmartLab) equipped with a one-dimensional high-speed Si strip detector

125 (Rigaku D/teX Ultra), utilizing $\mathrm{Cu} \mathrm{K \alpha}$ radiation (40 kV and $30 \mathrm{~mA}$ ). The structural

126 refinement was carried out by the Rietveld method in an iterative procedure using the

127 RIETAN-FP program. ${ }^{44}$ The crystal structure was visualized by the VESTA

128 software. ${ }^{45}$ The morphology of the sample was observed using field-emission

129 scanning electron microscopy (FE-SEM, Hitachi SU-8020). The electrochemical

130 properties of NVP-AP, NVP/AB-2h, and NVP/AB-8h were assessed using 2032-type

131 coin cells with a Bio-Logic VSP potentiostat, as described in our previous reports. ${ }^{37,40}$ 
132 The positive electrode was prepared by mixing active material, vapor-grown carbon

133 fibers (VGCFs), and polytetrafluoroethylene (PTFE) with agate mortar and pestle.

134 The resultant $\mathrm{NaVOPO}_{4} /$ conductive carbon (AB+VGCF)/PTFE weight ratio was

135 75:20:5. A metallic Na disc pressed onto an aluminum current collector was used as

136 the negative electrode. The $\mathrm{Na}[\mathrm{FSA}]-\left[\mathrm{C}_{3} \mathrm{C}_{1}\right.$ pyrr][FSA] (20:80 molar ratio) IL was

137 used as electrolyte according to our previous report. ${ }^{37,40}$ The mass loading and

138 thickness of the active material were approximately $2.0 \mathrm{mg} \mathrm{cm}^{-2}$ and $50 \mu \mathrm{m}$. For the

139 GITT, a current of $\mathrm{C} / 20\left(7.25 \mathrm{~mA} \mathrm{~g}^{-1}\right)$ was applied for $30 \mathrm{~min}$, followed by a $12 \mathrm{~h}$

140 relaxation, unless the system satisfied the $10 \mathrm{mV} \mathrm{h}^{-1}$ stability criterion earlier.

\section{Results and Discussion}

Fig. 1 shows the X-ray diffraction (XRD) pattern and Rietveld refinement results

143 for NVP-AP. The structure was refined in the monoclinic lattice with $P 2{ }_{1} / c$ space

144 group and lattice parameters $a=6.51960(9) \AA, b=8.44576(11) \AA, c=7.11499(10) \AA$,

$145 \beta=115.2591(4)^{\circ}, V=354.314(9) \AA^{3}$, and $Z=4$, which agrees well with previously

146 reported data for microcrystalline and single crystal samples. ${ }^{22,23}$ The related

147 structural parameters are given in the Supporting Information (Table S1). No impurity

148 was detected, as attested by the good agreement between the experimental and

149 calculated patterns. As shown in Fig. 2a, $\mathrm{NaVOPO}_{4}$ exhibits a structure built from

150 infinite chains of $\mathrm{VO}_{6}$ octahedra interconnected by $\mathrm{PO}_{4}$ tetrahedra, all in a 
151 corner-sharing fashion. The $\mathrm{VO}_{6}$ octahedra are distorted, as the vanadium atom is

152 displaced from the square plane comprising the four equatorial oxygen atoms toward

153 one apical oxygen atom. The $\mathrm{V}-\mathrm{O}_{\mathrm{b}}\left(\mathrm{O}_{\mathrm{b}}=\right.$ bridging oxygen $)$ bond lengths alternate

154 between longer and shorter bonds, resulting in the trans configuration of the $\left[\mathrm{VO}_{5}\right]_{\infty}$

155 chains (Fig. 2b, c). ${ }^{23,25}$ It was suggested that the distortion of the structural units and

156 the tilted connection between them creates additional space for Na migration. ${ }^{46}$

157 The XRD patterns of NVP-AP, NVP/AB-2h, and NVP/AB- $8 \mathrm{~h}$ are compared in

158 Fig. 3a. The XRD peaks of the ball-milled samples are remarkably broadened, and the

159 degree of broadening increases with the ball-milling time, indicative of the reduction

160 in the crystallite size. The Scherrer formula $D=1.33 \lambda / \beta \cos \theta$, where $\lambda$ is the $\mathrm{X}$-ray

161 wavelength, $\beta$ the integral breadth of the diffraction line, and $\theta$ the Bragg angle, was

162 used to estimate the crystallite size from the XRD data. ${ }^{47}$ The crystallite size D,

163 calculated as the average of the values corresponding to 4 discrete diffraction peaks

$164\left(110\right.$ at $18.4^{\circ}, 111$ at $26.7^{\circ}, \overline{1} 12$ at $27.4^{\circ}$, and 200 at $\left.30.3^{\circ}\right)$, was $106(6), 40(4)$, and $16532(4) \mathrm{nm}$ for the NVP, NVP/AB-2h, and NVP/AB-8h samples, respectively. FE-SEM 166 images of these samples are illustrated in Fig. 3b-d. The NVP-AP sample (Fig. 3b) is 167 composed of many submicron grains aggregated up to several microns, suggesting a 168 considerable grain growth even at the relatively low sintering temperature of $773 \mathrm{~K}$ and with a short annealing time. A similar phenomenon was observed for $\mathrm{NaVOP}_{2} \mathrm{O}_{7}$ 
170 synthesized at $673 \mathrm{~K}^{18}$ After ball-milling with $\mathrm{AB}$ (Fig. 3c and d), there was a

171 significant reduction in particle size, to approximately $100 \mathrm{~nm}$. The trend observed by

172 FE-SEM is consistent with that highlighted by XRD.

173 Fig. 4a-d show the typical galvanostatic charge-discharge curves of the

$174 \mathrm{NVP} / \mathrm{AB}-2 \mathrm{~h}$ and NVP/AB-8h electrodes in the three initial cycles at $5 \mathrm{~mA} \mathrm{~g}^{-1}$. For

$175 \mathrm{NVP} / \mathrm{AB}-2 \mathrm{~h}$, the galvanostatic profiles exhibit sloping curves without plateau, and the

176 reversible capacities are 40 and $74 \mathrm{mAh} \mathrm{g}^{-1}$ at $298 \mathrm{~K}$ and $363 \mathrm{~K}$, respectively. In

177 comparison with NVP/AB-2h, NVP/AB-8h shows a higher reversible capacity under

178 the same conditions, delivering 60 and $101 \mathrm{mAh} \mathrm{g}^{-1}$ at $298 \mathrm{~K}$ and $363 \mathrm{~K}$, respectively,

179 which correspond to $41 \%$ and $70 \%$ of the theoretical capacity. The average operating

180 potential of $3.6 \mathrm{~V} v s . \mathrm{Na}^{+} / \mathrm{Na}$ is noticeable, considering that this material does not

181 contain fluorine to facilitate the inductive effect. ${ }^{19,21}$ However, the capacity on the

182 first charge is always larger than that on the first discharge, especially at $363 \mathrm{~K}$,

183 suggesting the occurrence of an anodic parasitic reaction. To account for the

184 abnormally high initial charge capacity, charge-discharge tests were performed on

185 electrodes consisting of only ball-milled AB. Referring to Fig. S1, a large charge

186 capacity was observed in the first cycle, with an apparent decrease in the subsequent

187 cycle. This indicates that a parasitic reaction involving $\mathrm{AB}$ occurs, after energetic

188 ball-milling in the composite electrode, which contributes to the observed irreversible 
189 capacity during the first cycle. However, AB does not participate in the Na storage on

190 the subsequent cycling. In addition, the first-cycle capacity loss could also be ascribed

191 to Na-consuming reactions, such as the formation of a passivation layer on the

192 electrode. ${ }^{48}$ For comparison, almost no Na can be extracted from NVP-AP, which is

193 consistent with the previous report (Fig. S2). ${ }^{22}$ Pure $\mathrm{NaVOPO}_{4}$ may suffer from low

194 electronic conductivity as in the case of other phosphate battery electrode materials. ${ }^{49}$

195 The enhanced electrochemical properties of $\mathrm{NaVOPO}_{4} / \mathrm{AB}$ electrodes are therefore

196 attributed to the fine particles in close contact with the conductive carbon matrix, and

197 to the shortened $\mathrm{Na}$ transport path lengths due to the reduction in particle size.

198 Song et al. reported that the $\mathrm{NaVOPO}_{4} / \mathrm{AB}$ electrode exhibits a capacity of 90

$199 \mathrm{mAh} \mathrm{g}^{-1}$ in the voltage range of $2.0-4.4 \mathrm{~V}$ in $\mathrm{NaClO}_{4} / \mathrm{PC}$ electrolyte at room

200 temperature. $^{22}$ Taking into account that the capacity for a positive electrode in the

201 region above $2.5 \mathrm{~V}, 60 \mathrm{mAh} \mathrm{g}^{-1}$ obtained in the present IL electrolyte is thus similar

202 to that obtained in $\mathrm{NaClO}_{4} / \mathrm{PC}$ electrolyte at room temperature, ${ }^{22}$ and the capacity of

$203101 \mathrm{mAh} \mathrm{g}^{-1}$ measured at $363 \mathrm{~K}$ is quite remarkable. The voltage profiles also exhibit

204 a substantial difference with respect to the $\mathrm{NaClO}_{4} / \mathrm{PC}$ electrolyte, namely, a more

205 evident discharge pseudo-plateau is obtained in this study. Most importantly, the

206 increased capacity is mainly above $3.5 \mathrm{~V}$, which is essential for achieving high energy

207 density. These results confirm that a moderately elevated operating temperature can 
208 effectively enhance the utilization ratio of the active materials, leading to a higher

209 capacity. Similar findings were reported by other groups ${ }^{33,34,50}$ and by us..$^{39,41}$

210 The structural evolution of $\mathrm{NaVOPO}_{4}$ upon electrochemical cycling at $363 \mathrm{~K}$

211 was investigated through an ex situ XRD analysis. Comparison of XRD patterns for

212 the $\mathrm{NaVOPO}_{4} / \mathrm{AB}$ electrode at different charging and discharging states are presented

213 in Fig. S3. It can be noticed that charging of the electrode up to $4.2 \mathrm{~V}$ induces only

214 slight changes in the diffraction patterns (e.g., the intensity of the 111 peak relative to

215 that of the $\overline{1} 12$ peak increases upon charging). Since no pronounced new diffraction

216 peaks are detected, $\mathrm{NaVOPO}_{4}$ is considered to undergo topotactic $\mathrm{Na}$ extraction.

217 Some structural disorder may also occur for a low $\mathrm{Na}$ content as broadening of the

218 low-angle peaks is observed. ${ }^{51}$ Although the quality of the XRD pattern of the

219 electrochemically desodiated $\mathrm{NaVOPO}_{4}$ was unsatisfactory, Rietveld analysis was

220 performed under highly constrained conditions in order to determine the lattice

221 parameters (Table S2). The result suggests that desodiation of $\mathrm{NaVOPO}_{4}$

$222\left(\mathrm{Na}_{0.4} \mathrm{VOPO}_{4}\right)$ leads to a minor $(\sim 1.2 \%)$ decrease in volume, which is close to the

223 value between $\beta$-LiVOPO 4 and $\beta$-VOPO ${ }_{4}{ }^{52}$

224 The rate capability of the NVP/AB- $2 \mathrm{~h}$ and NVP/AB- $8 \mathrm{~h}$ electrodes at $363 \mathrm{~K}$ is

225 shown in Fig. 5a and b. The cells were charged to $4.2 \mathrm{~V}$ at a constant current density

226 of $\mathrm{C} / 10\left(14.5 \mathrm{~mA} \mathrm{~g}^{-1}\right)$, and subsequently discharged to $2.5 \mathrm{~V}$ at various rates. 
227 Although the discharge capacity declines with an increase in current density, a

228 sufficiently high rate capability is realized at $363 \mathrm{~K}$. Approximately $76 \%$ and $60 \%$ of

229 the maximum capacity observed at $5 \mathrm{~mA} \mathrm{~g}^{-1}$ is maintained at $5 \mathrm{C}$ and $10 \mathrm{C}$,

230 respectively, for both the NVP/AB-2h and NVP/AB-8h. The discharge capacity is still

231 clearly discernible up to a rate of $40 \mathrm{C}\left(5800 \mathrm{~mA} \mathrm{~g}^{-1}\right)$. The long-term cycling

232 performance of the NVP/AB-2h and NVP/AB-8h electrodes at a current density of 1

$233 \mathrm{C}$ is shown in Fig. 6a and b. Fairly stable cycling behavior with limited capacity

234 decay is observed at $298 \mathrm{~K}$ for both electrodes; when cycled at $363 \mathrm{~K}$, more than $74 \%$

235 of the initial capacity is retained after 300 cycles. The average coulombic efficiencies

236 over the course of the entire test are higher than $99.7 \%$ for all the cells investigated.

237 The good cyclability can be attributed to the minimal volume change experienced by

$238 \mathrm{NaVOPO}_{4}$ during $\mathrm{Na}$ extraction/insertion, as well as to the use of a chemically stable

239 IL electrolyte.

240 The kinetic behavior of the NVP/AB-8h electrode at $298 \mathrm{~K}$ and $363 \mathrm{~K}$ was

241 examined using the galvanostatic intermittent titration technique (GITT) (Fig. 7). As

242 shown in Fig. 7a, a relatively small overpotential is observed in the charge curves at

$243298 \mathrm{~K}$, while a larger overpotential is observed toward the end of discharge. This is

244 attributed to kinetic limitations, due to the high resistance in the particles, that hinder

$245 \mathrm{Na}^{+}$access to their centers. ${ }^{53}$ Other causes, such as the concentration polarization, 
246 may also account for the increased overpotential at the end of these curves. ${ }^{54}$ The

247 GITT curves at $363 \mathrm{~K}$ clearly show that the overpotential is suppressed in the full

248 range of voltage as compared to that at $298 \mathrm{~K}$, reflecting a lower kinetic barrier for

$249 \mathrm{Na}^{+}$insertion into this material. For both temperatures, there is no evidence of a

250 voltage plateau in the GITT data, implying that the electrochemical reaction

251 undergoes a single-phase rather than a two-phase mechanism. ${ }^{55}$ This assignment is

252 consistent with the ex situ XRD results above. Assuming that $\mathrm{Na}$ transport in the

253 electrode obeys Fick's second law, the chemical diffusion coefficient can be estimated

254 from the GITT curves using the following equation: ${ }^{.56,57}$

$$
D_{\mathrm{GITT}}=\frac{4}{\pi \tau}\left(\frac{m_{\mathrm{B}} V_{\mathrm{m}}}{M_{\mathrm{B}} S}\right)^{2}\left(\frac{\Delta E_{\mathrm{s}}}{\Delta E_{\tau}}\right)^{2} \quad\left(t<<L^{2} / D_{\mathrm{GITT}}\right)
$$

256 where $\tau$ is the time period of the current pulse, $m_{\mathrm{B}}$ is the mass of the electroactive

257 material, $V_{\mathrm{m}}$ and $M_{\mathrm{B}}$ are its molar volume and molecular weight, $S$ is the contact area

258 between the electrolyte and the electrode, $\Delta E_{\mathrm{s}}$ is the difference in the open circuit

259 voltage measured at the end of the relaxation period for two successive steps, $\Delta E_{\tau}$ is

260 the difference in cell voltage during the single titration current pulse, and $L$ is the

261 thickness of the electrode. This equation can be applied if there is a linear correlation

262 between $E_{\tau}$ and $\tau^{1 / 2}$ (Fig. S4). Because the contact area used is the geometric area, the

263 term apparent chemical diffusion coefficient is used here for $D_{\text {GITT }}$. It must be

264 mentioned that the actual surface area of the active material in contact with the 
265 electrolyte in composite electrode systems depends on the particle size of the active

266 material and its morphology, and must be larger than the geometric area, due to the

267 penetration of electrolyte. ${ }^{58}$ Care has been taken in the present study to minimize the

268 uncertainty in electrode physical parameters by performing the GITT measurement on

269 the same cell at 298 and $363 \mathrm{~K}$. It has been suggested that this technique gives

270 accurate results especially for small stoichiometric changes. ${ }^{56}$

271 Taking these aspects into consideration, the calculated $D_{\text {GITT }}$ at the initial stages

272 of charge and discharge is plotted as a function of cell voltage in Fig. $7 \mathrm{~b}$. The $D_{\text {GITT }}$

273 values range from $2 \times 10^{-12}$ to $1 \times 10^{-11} \mathrm{~cm}^{2} \mathrm{~s}^{-1}$ at $298 \mathrm{~K}$, and from $1 \times 10^{-11}$ to $3 \times$

$27410^{-11} \mathrm{~cm}^{2} \mathrm{~s}^{-1}$ at $363 \mathrm{~K}$. The diffusivity of $\mathrm{Na}^{+}$in $\mathrm{NaVOPO}_{4}$ is enhanced by $3-5$ times

275 by increasing the temperature from 298 to $363 \mathrm{~K}$, confirming the favorable kinetics at

276 elevated temperatures, and thus leading to improved electrochemical performance.

277 Furthermore, the obtained $D_{\text {GITT }}$ is comparable to that observed for layered oxides,

$278 \mathrm{O} 3-\mathrm{Na}\left[\mathrm{Ni}_{0.25} \mathrm{Fe}_{0.5} \mathrm{Mn}_{0.25}\right] \mathrm{O}_{2}$ and $\mathrm{Na}_{2} \mathrm{Ti}_{3} \mathrm{O}_{7}\left(\right.$ ca. $\left.10^{-12}-10^{-11} \mathrm{~cm}^{2} \mathrm{~s}^{-1}\right),{ }^{59,60}$ and is

279 considerably higher than that of other positive electrode materials such as $\mathrm{Na}_{4} \mathrm{Mn}_{9} \mathrm{O}_{18}$

280 (ca. $\left.10^{-16}-10^{-15} \mathrm{~cm}^{2} \mathrm{~s}^{-1}\right)^{61}$ and olivine $\mathrm{NaFePO}_{4}\left(c a \cdot 10^{-17} \mathrm{~cm}^{2} \mathrm{~s}^{-1}\right){ }^{62}$ which were

281 acquired by similar electrochemical methods. These results highlight the potential of

$282 \mathrm{NaVOPO}_{4}$ for high-power applications, although further improvements and

283 optimizations in synthesis and electrode formulation are required. 


\section{Conclusions}

285

In order to explore the enhanced kinetics at elevated temperatures, the

charge-discharge behavior of $\mathrm{NaVOPO}_{4}$ was investigated in

$287 \mathrm{Na}[\mathrm{FSA}]-\left[\mathrm{C}_{3} \mathrm{C}_{1}\right.$ pyrr] $[\mathrm{FSA}]$ ionic liquid electrolyte at 298 and $363 \mathrm{~K}$. Reversible

288 capacities of 60 and $101 \mathrm{mAh} \mathrm{g}^{-1}$ were achieved at 298 and $363 \mathrm{~K}$, respectively, as

289 well as adequate rate capability and cyclability. The apparent $\mathrm{Na}$ chemical diffusion

290 coefficient was evaluated by GITT analysis, which indicated that the $\mathrm{Na}^{+}$diffusivity

291 increases by $3-5$ times when the temperature increased from 298 to $363 \mathrm{~K}$. The

292 combined advantages of a moderately high operating voltage (3.6 V) and a large

293 theoretical capacity $\left(145 \mathrm{mAh} \mathrm{g}^{-1}\right)$ designate $\mathrm{NaVOPO}_{4}$ as a promising positive

294 electrode material for $\mathrm{Na}$ secondary batteries. Cationic substitution of $\mathrm{NaM}_{x} \mathrm{~V}_{1-x} \mathrm{OPO}_{4}$

$295\left(\mathrm{M}=\mathrm{Ti}^{3+}, \mathrm{Al}^{3+}, \mathrm{Fe}^{3+}\right)$ may represent a promising way to boot its performance and

296 decrease the consumption of vanadium.

\section{Acknowledgements}

298 This study was partly supported by Advanced Low Carbon Technology Research and

299 Development Program (ALCA) of Japan Science and Technology Agency (JST) and

300 Japanese Ministry of Education, Culture, Sports, Science and Technology (MEXT)

301 program “Elements Strategy Initiative to Form Core Research Center”. 


\section{References}

304

305

306

307

308

309

310

311

312

313

314

315

1. D. Larcher and J. M. Tarascon, Nature Chem., 7, 19 (2014).

2. V. Palomares, M. Casas-Cabanas, E. Castillo-Martinez, M. H. Han, and T. Rojo, Energy Environ. Sci., 6, 2312 (2013).

3. N. Yabuuchi, K. Kubota, M. Dahbi, and S. Komaba, Chem. Rev., 114, 11636 (2014).

4. M. S. Whittingham, Prog. Solid State Chem., 12, 41 (1978).

5. S. P. Ong, V. L. Chevrier, G. Hautier, A. Jain, C. Moore, S. Kim, X. H. Ma, and G. Ceder, Energy Environ. Sci., 4, 3680 (2011).

6. M. Okoshi, Y. Yamada, A. Yamada, and H. Nakai, J. Electrochem. Soc., 160, A2160 (2013).

7. E. Jonsson and P. Johansson, Phys. Chem. Chem. Phys., 14, 10774 (2012).

8. F. Sagane, T. Abe, Y. Iriyama, and Z. Ogumi, J. Power Sources, 146, 749 (2005).

9. T. Abe, H. Fukuda, Y. Iriyama, and Z. Ogumi, J. Electrochem. Soc., 151, A1120 (2004).

10. P. Serras, V. Palomares, A. Goni, I. G. de Muro, P. Kubiak, L. Lezama, and T. Rojo, J. Mater. Chem., 22, 22301 (2012).

11. Y. U. Park, D. H. Seo, H. Kim, J. Kim, S. Lee, B. Kim, and K. Kang, Adv. Funct. Mater., 24, 4603 (2014).

12. Z. L. Jian, W. Z. Han, X. Lu, H. X. Yang, Y. S. Hu, J. Zhou, Z. B. Zhou, J. Q. Li, W. Chen, D. F. Chen, and L. Q. Chen, Adv. Energy Mater., 3, 156 (2013).

13. K. Saravanan, C. W. Mason, A. Rudola, K. H. Wong, and P. Balaya, Adv. Energy Mater., 3, 444 (2013).

14. J. Barker, M. Y. Saidi, and J. L. Swoyer, Electrochem. Solid-State Lett., 6, A1 (2003). 
15. Y. U. Park, D. H. Seo, H. S. Kwon, B. Kim, J. Kim, H. Kim, I. Kim, H. I. Yoo, and K. Kang, J. Am. Chem. Soc., 135, 13870 (2013).

16. S. Y. Lim, H. Kim, J. Chung, J. H. Lee, B. G. Kim, J. J. Choi, K. Y. Chung, W. Cho, S. J. Kim, W. A. Goddard, Y. Jung, and J. W. Choi, Proc. Nat. Acad. Sci. U.S.A., 111, 599 (2014).

17. C. Deng and S. Zhang, ACS Appl. Mater. Interfaces, 6, 9111 (2014).

18. P. Barpanda, G. D. Liu, M. Avdeev, and A. Yamada, ChemElectroChem, 1, 1488 (2014).

19. A. K. Padhi, K. S. Nanjundaswamy, C. Masquelier, S. Okada, and J. B. Goodenough, J. Electrochem. Soc., 144, 1609 (1997).

20. A. Gutierrez, N. A. Benedek, and A. Manthiram, Chem. Mater., 25, 4010 (2013).

21. B. C. Melot, D. O. Scanlon, M. Reynaud, G. Rousse, J. N. Chotard, M. Henry, and J. M. Tarascon, ACS Appl. Mater. Interfaces, 6, 10832 (2014).

22. J. Song, M. W. Xu, L. Wang, and J. B. Goodenough, Chem. Commun., 49, 5280 (2013).

23. K. H. Lii, C. H. Li, T. M. Chen, and S. L. Wang. Z. Kristallogr., 197, 67 (1991).

24. E. J. Baran, M. B. Vassallo, and K. H. Lii, J. Raman Spectrosc., 25, 199 (1994).

25. S. Boudin, A. Guesdon, A. Leclaire, and M. M. Borel, Int. J. Inorg. Mater., 2, 561 (2000).

26. B. C. Melot and J. M. Tarascon, Acc. Chem. Res., 46, 1226 (2013).

27. A. Ponrouch, R. Dedryvere, D. Monti, A. E. Demet, J. M. A. Mba, L. Croguennec, C. Masquelier, P. Johansson, and M. R. Palacin, Energy Environ. Sci., 6, 2361 (2013).

28. A. Ponrouch, D. Monti, A. Boschin, B. Steen, P. Johansson, and M. R. Palacin, J. Mater. Chem. A, 3, 22 (2015). 
29. M. Armand, F. Endres, D. R. MacFarlane, H. Ohno, and B. Scrosati, Nature Mater., 8, 621 (2009).

30 D. R. MacFarlane, N. Tachikawa, M. Forsyth, J. M. Pringle, P. C. Howlett, G. D. Elliott, J. H. Davis, M. Watanabe, P. Simon, and C. A. Angell, Energy Environ. Sci., 7, 232 (2014).

31. D. Monti, E. Jonsson, M. R. Palacin, and P. Johansson, J. Power Sources, 245, $630(2014)$.

32. H. Yoon, H. J. Zhu, A. Hervault, M. Armand, D. R. MacFarlane, and M. Forsyth, Phys. Chem. Chem. Phys., 16, 12350 (2014).

33. L. S. Plashnitsa, E. Kobayashi, Y. Noguchi, S. Okasa, and J. Yamaki, J. Electrochem. Soc., 157, A536 (2010).

34. N. Wongittharom, C. H. Wang, Y. C. Wang, C. H. Yang, and J. K. Chang, ACS Appl. Mater. Interfaces, 6, 17564 (2014).

35. L. G. Chagas, D. Buchholz, L. M. Wu, B. Vortmann, and S. Passerini, J. Power Sources, 247, 377 (2014).

36. A. Fukunaga, T. Nohira, Y. Kozawa, R. Hagiwara, S. Sakai, K. Nitta, and S. Inazawa, J. Power Sources, 209, 52 (2012).

37. C. S. Ding, T. Nohira, K. Kuroda, R. Hagiwara, A. Fukunaga, S. Sakai, K. Nitta, and S. Inazawa, J. Power Sources, 238, 296 (2013).

38. K. Matsumoto, T. Hosokawa, T. Nohira, R. Hagiwara, A. Fukunaga, K. Numata, E. Itani, S. Sakai, K. Nitta, and S. Inazawa, J. Power Sources, 265, 36 (2014).

39. C. Y. Chen, K. Matsumoto, T. Nohira, and R. Hagiwara, Electrochem. Commun., 45, 63 (2014).

40. C. Y. Chen, K. Matsumoto, T. Nohira, C. S. Ding, T. Yamamoto, and R. Hagiwara, Electrochim. Acta, 133, 583 (2014). 
41. C. Y. Chen, K. Matsumoto, T. Nohira, and R. Hagiwara, J. Electrochem. Soc., 162, A176 (2015).

42. K. Amine, J. Liu, and I. Belharouak, Electrochem. Commun., 7, 669 (2005).

43. F. Mestre-Aizpurua, S. Hamelet, C. Masquelier, and M. R. Palacin, J. Power Sources, 195, 6897 (2010).

44. F. Izumi and K. Momma, Solid State Phenom., 130, 15 (2007).

45. K. Momma and F. Izumi, J. Appl. Crystallogr., 44, 1272 (2011).

46. R. Tripathi, S. M. Wood, M. S. Islam, and L. F. Nazar, Energy Environ. Sci., 6, 2257 (2013).

47. A. L. Patterson, Phys. Rev., 56, 978 (1939).

48. S. Komaba, T. Ishikawa, N. Yabuuchi, W. Murata, A. Ito, and Y. Ohsawa, ACS Appl. Mater. Interfaces, 3, 4165 (2011).

49. C. Delacourt, L. Laffont, R. Bouchet, C. Wurm, J. B. Leriche, M. Morcrette, J. M. Tarascon, and C. Masquelier, C. J. Electrochem. Soc., 152, A913 (2005).

50. N. Wongittharom, T. C. Lee, C. H. Wang, Y. C. Wang, and J. K. Chang, J. Mater. Chem. A, 2, 5655 (2014).

51. K. Trad, D. Carlier, L. Croguennec, A. Wattiaux, B. Lajmi, M. Ben Amara, and C. Delmas, J. Phys. Chem. C, 114, 10034 (2010).

52. J. Gaubicher, T. Le Mercier, Y. Chabre, J. Angenault, and M. Quarton, J. Electrochem. Soc., 146, 4375 (1999).

53. J. Liu, D. H. Chang, P. Whitfield, Y. Janssen, X. Q. Yu, Y. N. Zhou, J. M. Bai, J. Ko, K. W. Nam, L. J. Wu, Y. M. Zhu, M. Feygenson, G. Amatucci, A. Van der Ven, X. Q. Yang, and P. Khalifah, Chem. Mater., 26, 3295 (2014).

54. Z. L. Jian, H. J. Yu, and H. S. Zhou, Electrochem. Commun., 34, 215 (2013).

55. R. Berthelot, D. Carlier, and C. Delmas, Nature Mater., 10, 74 (2011).

56. W. Weppner and R. A. Huggins, J. Electrochem. Soc., 124, 1569 (1977). 
405 57. C. Delacourt, M. Ati, and J. M. Tarascon, J. Electrochem. Soc., 158, A741 (2011).

406 58. K. M. Shaju, G. V. S. Rao, and B. V. R. Chowdari, J. Mater. Chem., 13, 106 $407 \quad$ (2003).

408 59. S. M. Oh, S. T. Myung, C. S. Yoon, J. Lu, J. Hassoun, B. Scrosati, K. Amine, and 409 Y. K. Sun, Nano Lett., 14, 1620 (2014).

410 60. A. Rudola, K. Saravanan, C. W. Mason, and P. Balaya, P. J. Mater. Chem. A, 1, $4112653(2013)$.

412 61. Y. L. Cao, L. F. Xiao, W. Wang, D. W. Choi, Z. M. Nie, J. G. Yu, L. V. Saraf, Z. $413 \quad$ G. Yang, and J. Liu, Adv. Mater., 23, 3155 (2011).

414 62. Y. J. Zhu, Y. H. Xu, Y. H. Liu, C. Luo, and C. S. Wang, Nanoscale, 5, 780 (2013). 


\section{Figure captions}

416 Figure 1. X-ray diffraction pattern with Rietveld refinement of $\mathrm{NaVOPO}_{4}\left(R_{\mathrm{wp}}=\right.$

$4174.38 \%$ and $R_{\mathrm{p}}=3.13 \%$ ): experimental data (red dots), calculated pattern (black line),

418 Bragg positions (green bars) and difference curve (blue line).

419 Figure 2. Structure of $\mathrm{NaVOPO}_{4}$. (a) Crystal structure of $\mathrm{NaVOPO}_{4}$, with $\mathrm{VO}_{6}$ and

$420 \mathrm{PO}_{4}$ polyhedra shown in blue and gray, respectively. The $\mathrm{Na}, \mathrm{Fe}$ and $\mathrm{O}$ atoms are

421 colored green, navy, and orange, respectively; (b) distorted VO6 octahedral unit; (c) a

$422\left[\mathrm{VO}_{5}\right]_{\infty}$ chain in trans configuration with staggered $\mathrm{VO}_{6}$ octahedra.

423 Figure 3. (a) X-ray diffraction patterns of as-prepared $\mathrm{NaVOPO}_{4}(\mathrm{NVP}-\mathrm{AP})$ and

$424 \mathrm{NaVOPO}_{4}$ ball milled with $\mathrm{AB}$ for $2 \mathrm{~h}$ and $8 \mathrm{~h}$ (NVP/AB-2h and NVP/AB-8h). SEM

425 images of (b) NVP, (c) NVP/AB-2h, and (d) NVP/AB-8h.

426 Figure 4. Galvanostatic charge-discharge curves for the NVP/AB-2h and

$427 \mathrm{NVP} / \mathrm{AB}-8 \mathrm{~h}$ electrodes: $\mathrm{Na} / \mathrm{Na}[\mathrm{FSA}]-\left[\mathrm{C}_{3} \mathrm{C}_{1}\right.$ pyrr $][\mathrm{FSA}] / \mathrm{NVP} / \mathrm{AB}-2 \mathrm{~h}$ cell at (a) $298 \mathrm{~K}$

428 and (b) $363 \mathrm{~K} ; \mathrm{Na} / \mathrm{Na}[\mathrm{FSA}]-\left[\mathrm{C}_{3} \mathrm{C}_{1}\right.$ pyrr][FSA]/NVP/AB-8h cell at (c) $298 \mathrm{~K}$ and (d)

$429363 \mathrm{~K}$. Cut-off voltage: $2.5-4.2 \mathrm{~V}$. Current density: $5 \mathrm{~mA} \mathrm{~g}^{-1}$. Note the different 430 capacity scale in panel (d). 
431 Figure 5. Discharge curves of the (a) NVP/AB-2h and (b) NVP/AB-8h electrodes at

432 various current densities at $363 \mathrm{~K}$. The cells were charged to $4.2 \mathrm{~V}$ at a constant rate 433 of $\mathrm{C} / 10\left(14.5 \mathrm{~mA} \mathrm{~g}^{-1}\right)$.

434 Figure 6. Cycling performance and coulombic efficiency (C.E.) of the (a)

$435 \mathrm{NVP} / \mathrm{AB}-2 \mathrm{~h}$ and (b) NVP/AB-8h electrodes at 298 and $363 \mathrm{~K}$. Cut-off voltage:

$436 \quad 2.5-4.2$ V. Current density: $1 \mathrm{C}\left(145 \mathrm{~mA} \mathrm{~g}^{-1}\right)$.

437 Figure 7. (a) GITT evaluation of the NVP/AB-8h electrode at $298 \mathrm{~K}$ and $363 \mathrm{~K}$.

438 Conditions: 30 min charging/discharging segments at $\mathrm{C} / 20\left(7.25 \mathrm{~mA} \mathrm{~g}^{-1}\right)$ followed by

$43912 \mathrm{~h}$ relaxation. (b) Chemical diffusion coefficient of $\mathrm{Na}$ ions in $\mathrm{NaVOPO}_{4}\left(D_{\text {GITT }}\right)$

440 calculated from GITT as a function of cell voltage during charge (open symbols) or 441 discharge (solid symbols). 


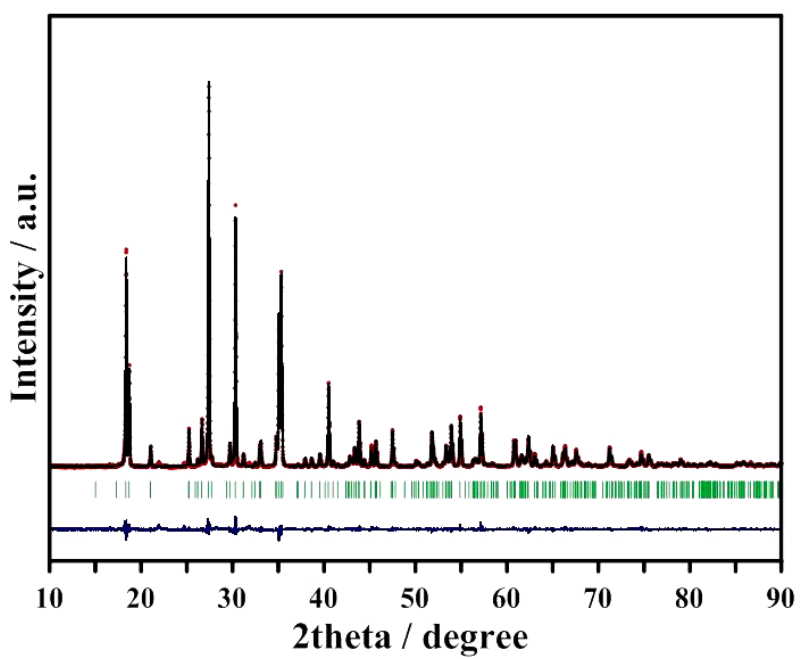

444

Figure 1

445

446

447

448

449

(a)

(b)

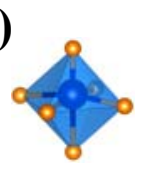

(c)

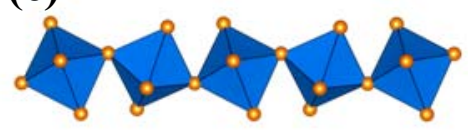

451

Figure 2 
(a)
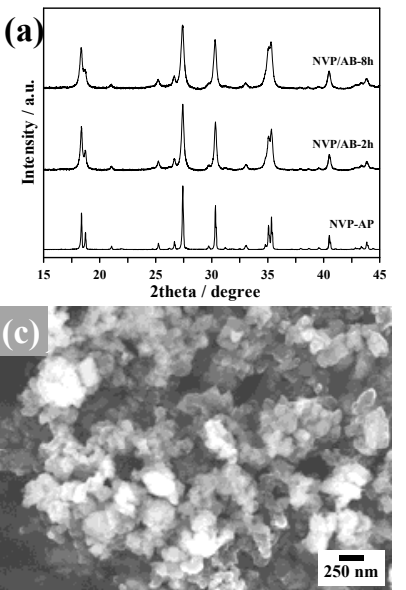

Figure 3
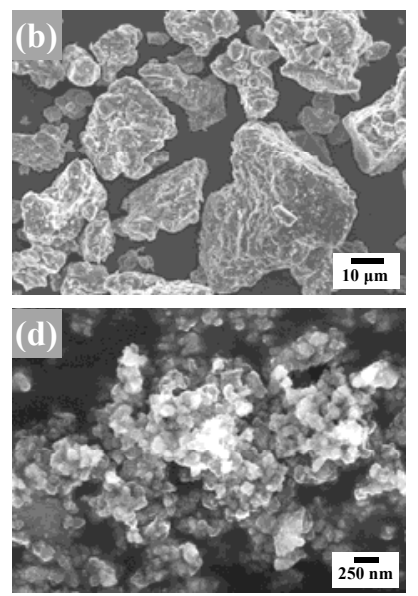

455

456

457

458

459

460

461
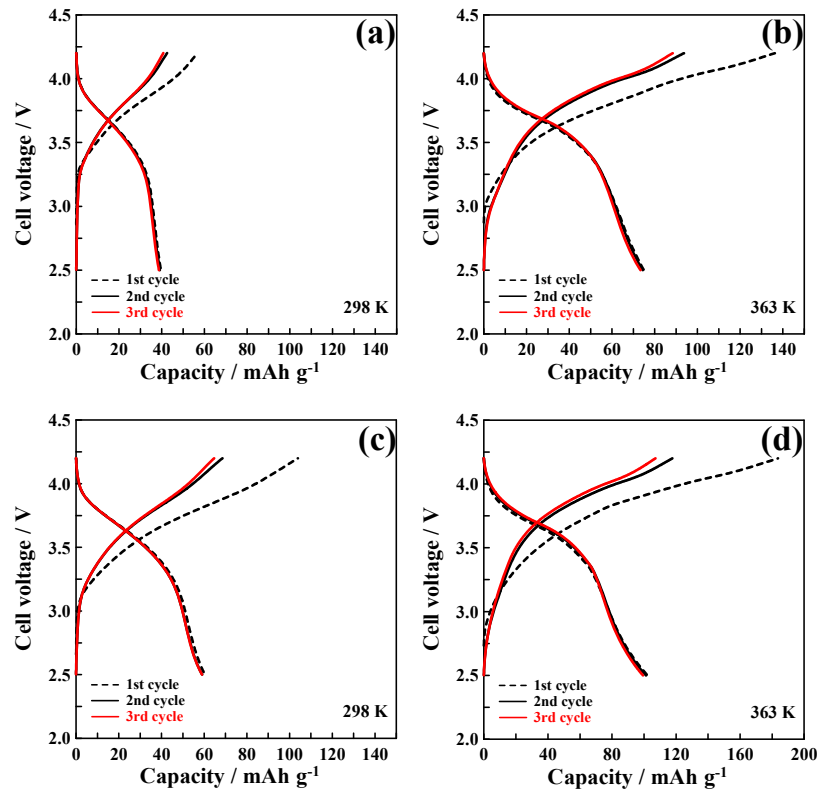

462

463

Figure 4

464 

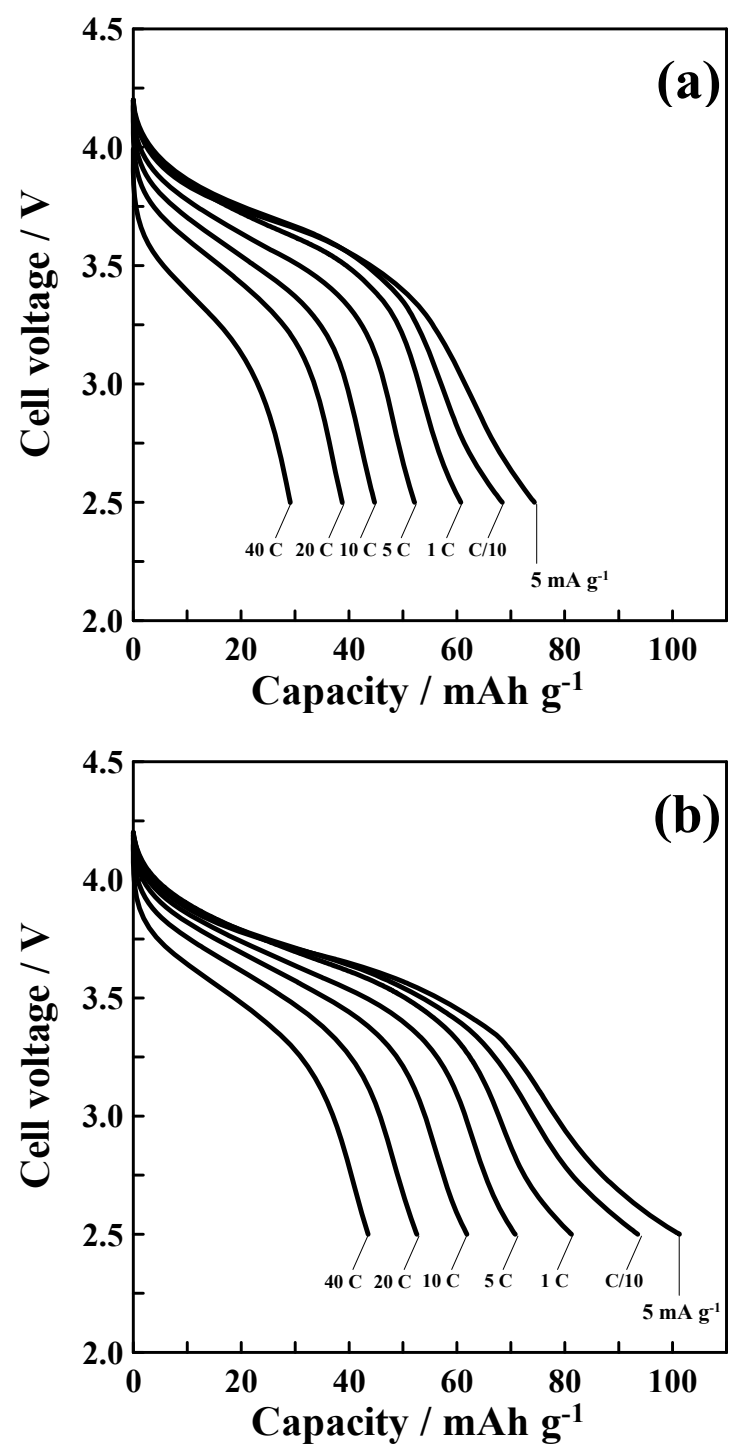

466

Figure 5

467 
468
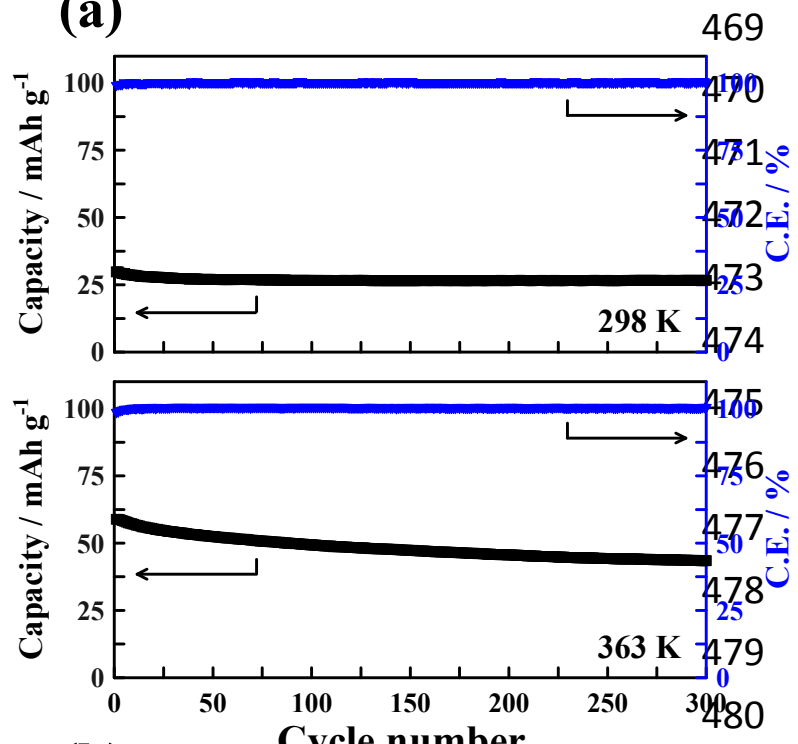

(b) Cycle number 481
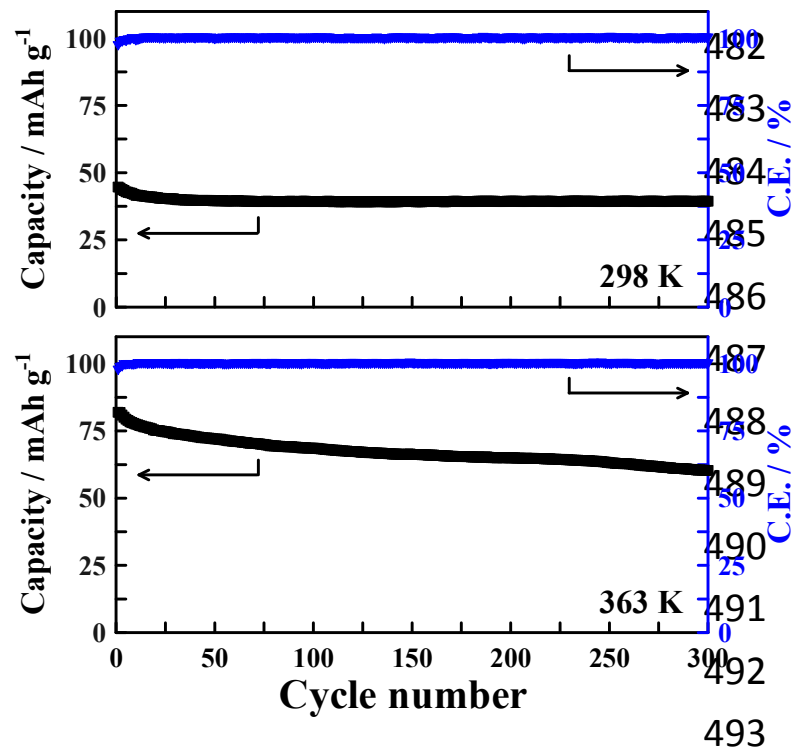

$494 \quad$ Figure 6 
496
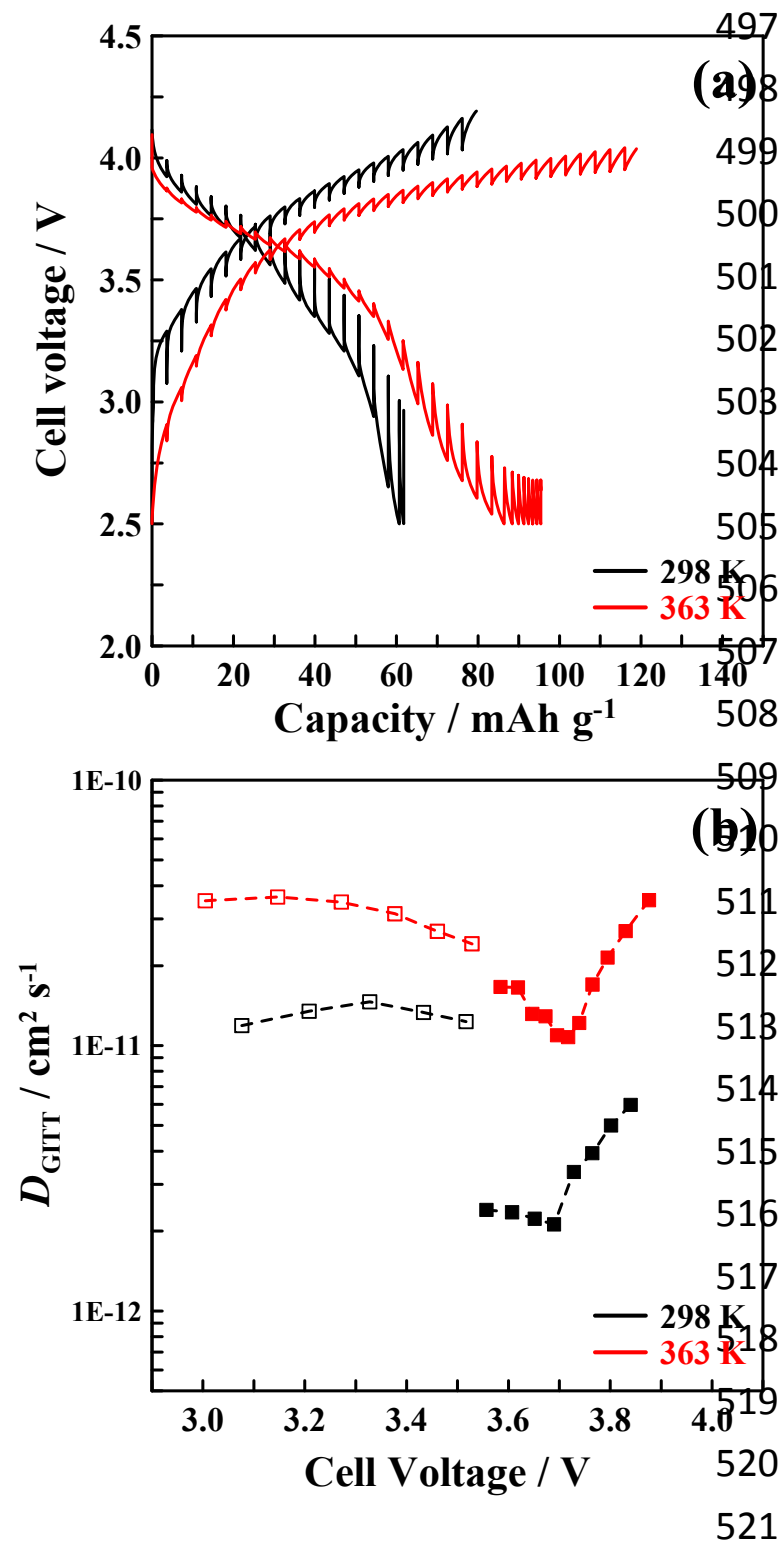

$522 \quad$ Figure 7 